\title{
Cytogenomic characterization of three murine malignant mesothelioma tumor cell lines
}

\author{
Eva Wahlbuhl ${ }^{1}$, Thomas Liehr ${ }^{{ }^{*}}$ (D), Martina Rincic ${ }^{2}$ and Shaymaa Azawi ${ }^{1}$
}

\begin{abstract}
Background: Malignant mesothelioma (MM) is a rare aggressive cancer primary located in pleura and lung. MMs can be divided into biphasic, epithelioid and sarcomatoid subtypes. In majority of cases MMs are induced by asbestos fiber exposure. As latency period after asbestos exposure ranges between $\sim 10$ and 60 years MMs are mainly observed in elder people. Human MM, being a rare tumor type, lacks detailed cytogenetic data, while molecular genetic studies have been undertaken more frequently. However, murine MM cell lines are also regularly applied to get more insight into MM biology and to test new therapy strategies.
\end{abstract}

Results: Here the murine MM cell lines AB1, AB22 and AC29 were studied by molecular cytogenetics and molecular karyotyping. Interestingly, yet there were no genetic or genomic studies undertaken for these already in 1992 established cell lines. The obtained data on genomic imbalances in these murine cell lines was translated into the human genome as previously reported based on human and murine genomic browsers.

Conclusions: It turned out that all three cell lines showed high similarities in copy number variants as observed typically in human MM. Also, all three cell lines were most similar to human epithelioid MMs, and should be used as models therefore.

Keywords: Murine multicolor banding (mcb), Array comparative genomic hybridization (aCGH), Malignant mesothelioma, Murine cell line, AB1, AB22, AC29

\section{Background}

Malignant mesothelioma (MM) is a rare aggressive tumor-family of pleura and lung, with an incidence of about $0.002 \%[1,2]$. In most of the cases, MMs are located in pleural mesothelium, and only rarely in peritoneal cavities, tunica vaginalis or pericardium. MM can be specifically promoted by exposure to asbestos fibers $[3,4]$. Besides working with asbestos, accordingly contaminated buildings provide an additional, often unrecognized problem, where affected person can undergo

*Correspondence: Thomas.Liehr@med.uni-jena.de

1 Jena University Hospital, Institute of Human Genetics, Friedrich Schiller University, Am Klinikum 1, 07747 Jena, Germany

Full list of author information is available at the end of the article asbestos inhalation, ingestion, or less often, severe exposures via the skin $[3,5]$. The latency periods for MM after asbestos exposure can range from 1 to 6 decades, and the median age of onset is 72 years [6].

Numerous genetic changes are involved in MM. These include numerical and structural chromosomal aberrations and molecular genetically detectable alterations in the cellular signal transduction pathways, among others caused by activation of oncogenes or loss of tumor suppressor genes [5]. In human the genes cyclin-dependent kinase inhibitor 2A (CDKN2A), neurofibromatosis type 2 (NF2), the breast cancer associated gene 1 (BRCA1) associated protein 1 (BAP1) and tumorsuppressorprotein 53 (TP53) genes seem to be major players in MM-pathogenesis and -progression [7-16]. original author(s) and the source, provide a link to the Creative Commons licence, and indicate if changes were made. The images or other third party material in this article are included in the article's Creative Commons licence, unless indicated otherwise in a credit line to the material. If material is not included in the article's Creative Commons licence and your intended use is not permitted by statutory regulation or exceeds the permitted use, you will need to obtain permission directly from the copyright holder. To view a copy of this licence, visit http://creativecommons.org/licenses/by/4.0/. The Creative Commons Public Domain Dedication waiver (http://creativeco mmons.org/publicdomain/zero/1.0/) applies to the data made available in this article, unless otherwise stated in a credit line to the data. 
Histomorphologically and according to their growth parameters, MM can be divided into the following, most frequently observed subtypes: (1) biphasic, (2) epithelioid and (3) sarcomatoid. Different median survival times were attributed to each subtype; the best prognosis has the epithelioid, while the worst one has the sarcomatoid subtype [13, 17].

As MM is an aggressive tumor with poor prognosis, there is ongoing research to better understand the biology of this cancer type $[18,19]$. Therefore, also animal models, including murine tumor cell lines are regularly applied, also because human and mouse genomes show homologies within coding sequences of up to $97 \%$ [20]. In 1992 Davis and coworkers inoculated asbestos fibers into female BALB/c and CBA mice and established successfully $12 \mathrm{MM}$ cell lines from tumor ascites cells [21]. Here two of these cell lines derived from BALB/c mice, i.e. $A B 1$ and $A B 12$, and one of them from CBA mice (AC29) were studied. Strikingly, in none of these cell lines (cyto) genetic research was undertaken yet to characterize their cytogenomic content. However, the latter data are important to use such cell lines in the best suited way to answer questions about MM-biology or to apply them in tests for new treatment options, i.e. for drug tests meant for the corresponding MM subtype.

\section{Results}

\section{Molecular cytogenetics}

\section{Ab1}

This cell line showed the following hypotetraploid composite karyotype (Fig. 1a) 73 80<4n>,-X,-X,der(1)t(1;2)(H5;F1), $\operatorname{der}(1) \mathrm{t}(1 ; 2)(\mathrm{H} 5 ; \mathrm{F} 1),+\operatorname{der}(1) \mathrm{t}(1 ; 2)(\mathrm{C} 1 ; \mathrm{F} 1),-2, \operatorname{der}(2)(2 \mathrm{~A} 1 \rightarrow$ $2 \mathrm{H} 4:: 6 \mathrm{~F} 3 \sim \mathrm{G} 1 \rightarrow 6 \mathrm{E} 1:: 6 \mathrm{~F} 3 \sim \mathrm{G} 1 \rightarrow 6 \mathrm{qter}), \operatorname{der}(2)(2 \mathrm{~A} 1 \rightarrow$ $2 \mathrm{H} 4:: 6 \mathrm{~F} 3 \sim \mathrm{G} 1 \rightarrow 6 \mathrm{E} 1:: 6 \mathrm{~F} 3 \sim \mathrm{G} 1 \rightarrow 6 \mathrm{qter}), \operatorname{der}(2) \mathrm{t}(2 ; 19)$ $(\mathrm{E} 3 ; \mathrm{D} 1),+3, \operatorname{der}(6) \mathrm{t}(2 ; 6)(\mathrm{H} 1 ; \mathrm{E} 1), \operatorname{der}(6) \mathrm{t}(2 ; 6)(\mathrm{H} 1 ; \mathrm{E} 1), \operatorname{der}(7)$ $\mathrm{t}(7 ; 19)(\mathrm{E} 3 ; \mathrm{D} 1), \operatorname{dic}(9 ; 19)(\mathrm{A} 1 ; \mathrm{D} 3), \operatorname{dic}(9 ; 19)(\mathrm{A} 1 ; \mathrm{D} 3), \operatorname{del}(13)$ (A5),dic(13;17)(A1;A1),dic(13;17)(A1;A1),der(15)t(15;?) (E1?;?),+der(15)(15pter $\rightarrow 15 \mathrm{E} 1:: 17 \mathrm{~B} \rightarrow 17 \mathrm{E} 3:: 17 \mathrm{E} 3 \rightarrow 17 \mathrm{~B}:)$, $+\operatorname{der}(15)(15 p t e r \rightarrow 15 \mathrm{~B} 2:: 17 \mathrm{~B} \rightarrow 17 \mathrm{E} 3:: 17 \mathrm{E} 3 \rightarrow 17 \mathrm{~B}:),-16,-17,-$ 17[11],-18[10],del(19)(D1),del(19)(D1).

In Fig. 1b examples of mcb experiments are shown for chromosomes 1, 2 and 6 , which enabled the characterization of the $\operatorname{der}(1) \mathrm{t}(1 ; 2)(\mathrm{C} 1 ; \mathrm{F} 1)$, the $\operatorname{der}(1) \mathrm{t}(1 ; 2)(\mathrm{H} 5 ; \mathrm{F} 1) \mathrm{x} 2$ and the $\operatorname{der}(2)(2 \mathrm{~A} 1 \rightarrow 2 \mathrm{H} 4:: 6 \mathrm{~F} 3 \sim \mathrm{G} 1 \rightarrow 6 \mathrm{E} 1:: 6 \mathrm{~F} 3 \sim \mathrm{G} 1 \rightarrow 6 \mathrm{qt}$ er)x2.

\section{Ab22}

The tumor cell line AB22 was near tetraploid (Fig. 2a) here the composite karyotype: $73 \sim 79<4 \mathrm{n}>,-\mathrm{X},-\mathrm{X}, \operatorname{der}(\mathrm{X})$ $\mathrm{t}(\mathrm{X} ; 6)(\mathrm{C} \sim \mathrm{D} ; \mathrm{C} 1), \operatorname{der}(\mathrm{X})(\mathrm{XA} 1 \rightarrow \mathrm{XC} \sim \mathrm{D}:: 6 \mathrm{C} 1 \rightarrow 6 \mathrm{G} 2:: \mathrm{XF1}$ $\rightarrow$ Xqter),dic(3;3)(A1;A1),del(3)(A3F1),der(4)(4A1 $\rightarrow 4 \mathrm{C} 3$ $:: 4 \mathrm{C} 3:: 4 \mathrm{C} 5 \rightarrow 4 \mathrm{C} 7:: 4 \mathrm{C} 7 \rightarrow 4 \mathrm{C} 5:: 2 \mathrm{~F} 3 \rightarrow 2 \mathrm{qter}), \operatorname{der}(4)(4 \mathrm{~A} 1 \rightarrow$ $4 \mathrm{C} 3:: 4 \mathrm{C} 3:: 4 \mathrm{C} 5 \rightarrow 4 \mathrm{C} 7:: 4 \mathrm{C} 7 \rightarrow 4 \mathrm{C} 5:: 2 \mathrm{~F} 3 \rightarrow 2 \mathrm{qter}),-5, \operatorname{der}(5)$

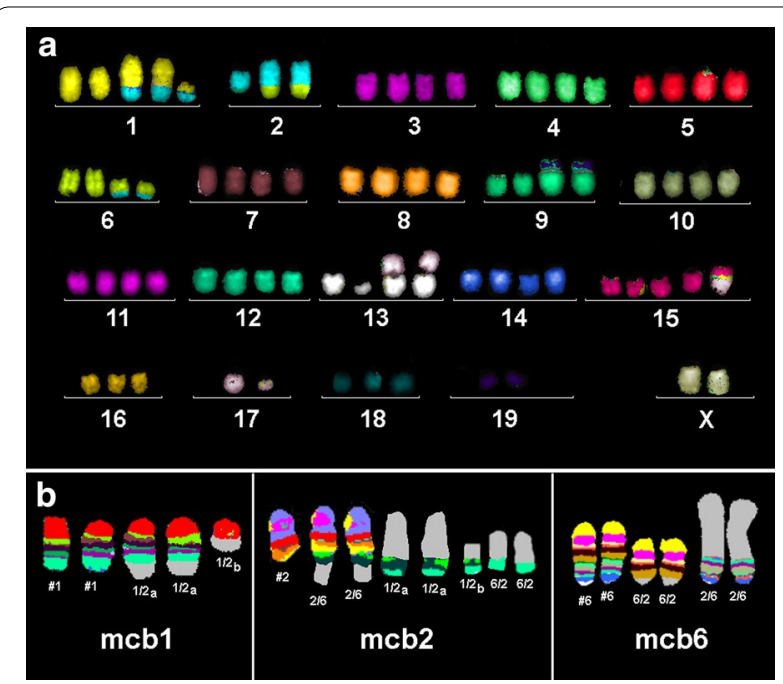

Fig. 1 a Results of mFISH using all 21 murine whole chromosome paints as probes applied on murine MM cell line AB1 are shown here. $\mathbf{b}$ Typical pseudocolorbanding-results for murine multicolor banding (mcb) as applied on cell line AB1 for chromosomes 1 (mcb1), 2 (mcb2) and 6 (mcb6). Derivative chromosomes are shown as $1 / 2_{\mathrm{a}}=\operatorname{der}(1) \mathrm{t}(1 ; 2)(\mathrm{H} 5 ; \mathrm{F} 1), 1 / 2_{\mathrm{b}^{\prime}}=\operatorname{der}(1) \mathrm{t}(1 ; 2)(\mathrm{C} 1 ; \mathrm{F} 1), 2 / 6=\operatorname{der}(2)(2 \mathrm{~A} 1$ $\rightarrow 2 \mathrm{H} 4: 6 \mathrm{~F} 3 \sim \mathrm{G} 1 \rightarrow 6 \mathrm{E} 1:: 6 \mathrm{~F} 3 \sim \mathrm{G} 1 \rightarrow 6 \mathrm{qter})$ and $6 / 2=\operatorname{der}(6) t(2 ; 6)(\mathrm{H} 1 ; \mathrm{E} 1)$; normal chromosomes are labeled by \# and chromosome number

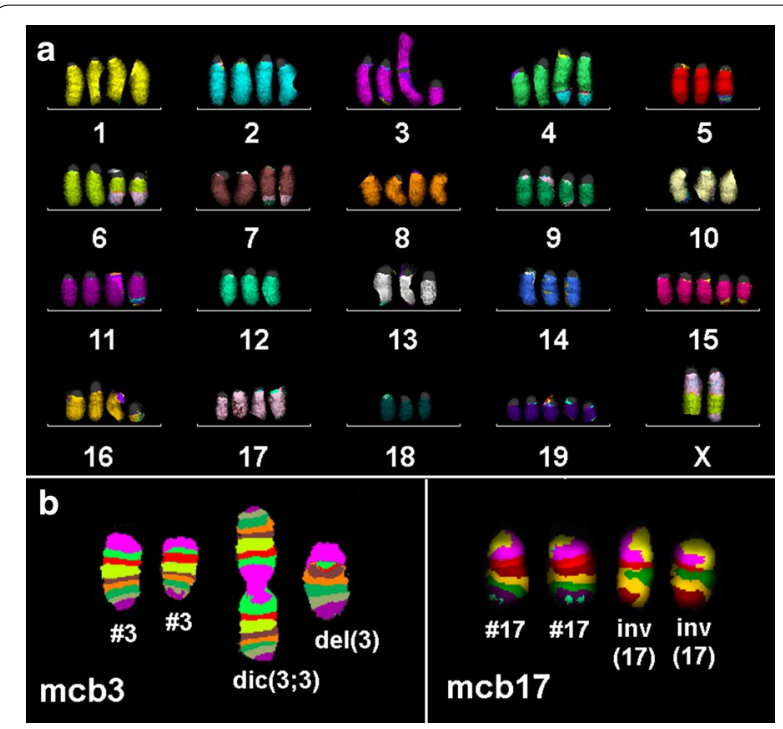

Fig. 2 mFISH (a) and selected mcb results (b) for murine MM cell line AB22. For mcb3 two normal chromosomes (\#3), a dic(3;3)(A1;A1) (dic(3;3)) and a del(3)(A3F1) (del(3)) are depicted. Also application of mcb17 revealed the presence of two normal chromosomes 17 (\#17) and two chromosomes 17 with inversion inv(17)(CE5) (inv(17))

$\mathrm{t}(5 ; 11)(\mathrm{G} 2 ; \mathrm{D} \sim \mathrm{E}), \operatorname{der}(6) \mathrm{t}(\mathrm{X} ; 6)(\mathrm{D} ; \mathrm{C} 1), \operatorname{der}(6) \mathrm{t}(\mathrm{X} ; 6)$ $(\mathrm{D} ; \mathrm{C} 1), \operatorname{der}(7) \mathrm{t}(7 ; 9)(\mathrm{F} 4 ; \mathrm{F} 1), \operatorname{der}(7) \mathrm{t}(7 ; 9)(\mathrm{F} 4 ; \mathrm{F} 1),-10,-12,-$ $13,-14, \operatorname{der}(15) \mathrm{t}(5 ; 15)(\mathrm{G} 2 ; \mathrm{E}), \operatorname{der}(15) \mathrm{t}(5 ; 15)(\mathrm{G} 2 ; \mathrm{E})$, der $(15)$ 
$(15 \mathrm{pter} \rightarrow 15 \mathrm{E}:: 6 \mathrm{D} \rightarrow 6 \mathrm{E}:: 15 \mathrm{E} \rightarrow 15 \mathrm{qter}),+\operatorname{der}(15)(15 \mathrm{~A} 1 \rightarrow$ $15 \mathrm{E}:: 6 \mathrm{D} \rightarrow 6 \mathrm{E}:: 15 \mathrm{E} \rightarrow 15 \mathrm{qter}),+\operatorname{der}(15)(15 \mathrm{pter} \rightarrow 15 \mathrm{E}:: 6 \mathrm{D}$ $\rightarrow 6 \mathrm{E}:: 15 \mathrm{E} \rightarrow 15 \mathrm{qter}), \operatorname{del}(16)(\mathrm{B} 2), \operatorname{der}(16)(\mathrm{pter} \rightarrow \mathrm{B} 2:: \mathrm{B} 1-$ $>$ qter), inv(17)(CE5),inv(17)(CE5),-18,+19.

Here examples for the mcb characterization of $\operatorname{dic}(3 ; 3)$ $(\mathrm{A} 1 ; \mathrm{A} 1)$ and $\operatorname{del}(3)(\mathrm{A} 3 \mathrm{~F} 1)$ by mcb3 and of inv(17)(CE5)x2 are shown in Fig. 3b.

\section{Ac29}

AC29 turned out to be hyper-triploid with one main clone (90\%) and one smaller subclone (10\%). The main clone karyotype (Fig. 3a) had the following karyotype: $63<3 n>, X,-X$, $\operatorname{der}(\mathrm{X})($ pter $\rightarrow$ A1::A2 $\rightarrow$ qter $), \operatorname{der}(1)($ pter $\rightarrow$ D $::$ E $4 \rightarrow$ $\mathrm{G}:: \mathrm{H} 2 \rightarrow$ qter $)$,der(1)(pter $\rightarrow$ C5::C2 $\rightarrow$ qter), del(2)(E2E5), $\operatorname{der}(2)(2$ pter $\rightarrow$ 2H3::19C3 $\rightarrow$ 19D2::11D $\rightarrow 11$ qter $),+\operatorname{del}(3)$ (A3E3), $+\operatorname{del}(3)(\mathrm{A} 3 \mathrm{E} 3),+\operatorname{del}(4)(\mathrm{C} 4), \operatorname{der}(5) \mathrm{t}(5 ; 6)(\mathrm{B} ; \mathrm{B} 3),-$ 6 ,der(6)t $(6 ; 12)(\mathrm{G} 1 ; \mathrm{C} 2),+\operatorname{der}(8)(8 \mathrm{pter} \rightarrow 8 \mathrm{~A} 3:: 8 \mathrm{~B} 3 \rightarrow 8 \mathrm{E} 2$ : $: 18 \mathrm{D} \rightarrow 18 \mathrm{E} 4:: 1 \mathrm{E} 4 \rightarrow 1 \mathrm{G}:: 18 \mathrm{D} \rightarrow 18 \mathrm{E} 4:: 1 \mathrm{E} 4 \rightarrow 1 \mathrm{G}:: 18 \mathrm{E} 4 \rightarrow$ $18 \mathrm{D}:: 1 \mathrm{E} 4 \rightarrow 1 \mathrm{G}), \operatorname{dic}(9 ; 15)(\mathrm{A} 1 ; \mathrm{A} 1), \operatorname{del}(11)(\mathrm{B} 4 \mathrm{E} 1), \operatorname{der}(11)$ $($ pter $\rightarrow$ B4::A2 $\rightarrow$ qter $)$,der(11)t $(2 ; 11)(H 3 ; D), \operatorname{der}(12) t(6 ; 12)$ (G1;C2),del(13)(A5B),der(17)t(11;17)(D;E5),der(17)(17pter $\rightarrow$ 17B $\sim$ C::6B1 $\rightarrow$ 6G3::6B1 $\rightarrow$ 6G3::17B $\sim \mathrm{C} \rightarrow 17 \mathrm{E} 5:: 2 \mathrm{H} 3 \rightarrow 2 \mathrm{qter})$, $\operatorname{der}(17)(17$ pter $\rightarrow$ 17E5::17E4 $\rightarrow$ 17E5::11E1 $\rightarrow$ 11qter),der(18) $\mathrm{t}(5 ; 18)(\mathrm{B} 1 ; \mathrm{D} 3), \operatorname{del}(18)(\mathrm{B} 1 \mathrm{C}),+\operatorname{mar} 1,+\operatorname{mar} 2$.

The subclone was just characterized by a translocation between chromosome 12 and $13\{\operatorname{der}(13) t(13) t(12 ; 13)\}$ instead of $\operatorname{del}(13)(\mathrm{A} 5 \mathrm{~B})$ compared to the main clone (Fig. 3a).

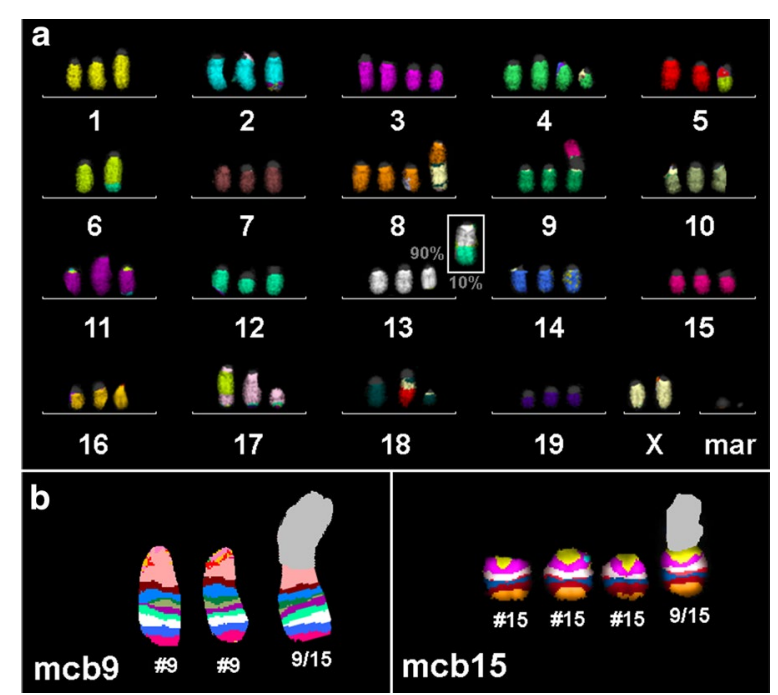

Fig. 3 a mFISH result of the main clone being present in $90 \%$ of the cell line AC29 is shown here. The only difference in the subclone comprising $10 \%$ of the cells is that the del(13)(A5B) is replaced by a der(13)t(13)t(12;13) as shown in white square. b Result for mcb9 and 15 highlight the $\operatorname{dic}(9 ; 15)(\mathrm{A} 1 ; \mathrm{A} 1)$ here labeled as 9/15
As examples for mcb the characterization of the $\operatorname{dic}(9 ; 15)(\mathrm{A} 1 ; \mathrm{A} 1)$ is shown in Fig. 3b.

Two marker chromosomes could be resolved here, neither by multicolor fluorescence in situ hybridization using all 21 murine whole chromosome paints as probes (mFISH-Fig. 3a) nor by mcb. Thus, most likely they are derivatives of the centromere-near region of any of the murine chromosomes-subband A1, which do not specifically stain by any euchromatic DNA-probe. Accordingly, the marker chromosomes could be left overs of the $\operatorname{dic}(9 ; 15)(\mathrm{A} 1 ; \mathrm{A} 1)$ and $\operatorname{del}(?)(\mathrm{A} 1)$.

\section{$\mathrm{aCGH}$}

Array comparative genomic hybridization (aCGH) data (Additional file 1: Table 1) together with which FISH results could be summarized in Figs. 4a, 5a and 6a. These results were translated to the corresponding homologous regions in the human genome as depicted in Figs. 4b, 5b and 6b. All in the evaluation included imbalances were larger than 3.5 mega base pairs.

\section{Data-analyses}

The common aberrations and cytogenetic changes that frequently occur in MM [22] revealed for all three cell lines to be less similar to human biphasic MM subtype (Table 1). According to Table 1, AB1 has 14/16 (88\%) aberrations in common with human epithelioid and 17/21 (81\%) aberrations with human sarcomatoid MMs. For AB22 it was 18/20 (94\%) and 17/21 (81\%) concordance to human epithelioid and sarcomatoid MMs, respectively. And for AC29 similarities of human epithelioid or sarcomatoid MMs was 15/20 (75\%) versus 15/22 (68\%). Thus, all three cell lines seemed to be best suited as models for human epithelioid MMs.

Also in Table 2 region, where four tumor suppressor genes meant to play important role in human MM are localized, were checked for copy number variant presence in the three studied murine MM cell lines. No correlations were found here.

\section{Conclusions}

The murine MM cell lines AB1, AB22 and AC29 were studied in this paper for the first time by molecular cytogenetics combined with aCGH. This enabled to determine their genetic alterations and imbalances and align these with human MMs. mFISH using whole chromosome painting probes revealed the general characteristics of the cell lines, like the ploidy, clonal and nonclonal changes as well as numerical and intrachromosomal structural aberrations. By mcb interchromosomal alterations as duplications, deletions or inversions, and chromosomal breakpoints involved could be uncovered, as previously reported [23-28]. The aCGH data was aligned with the 

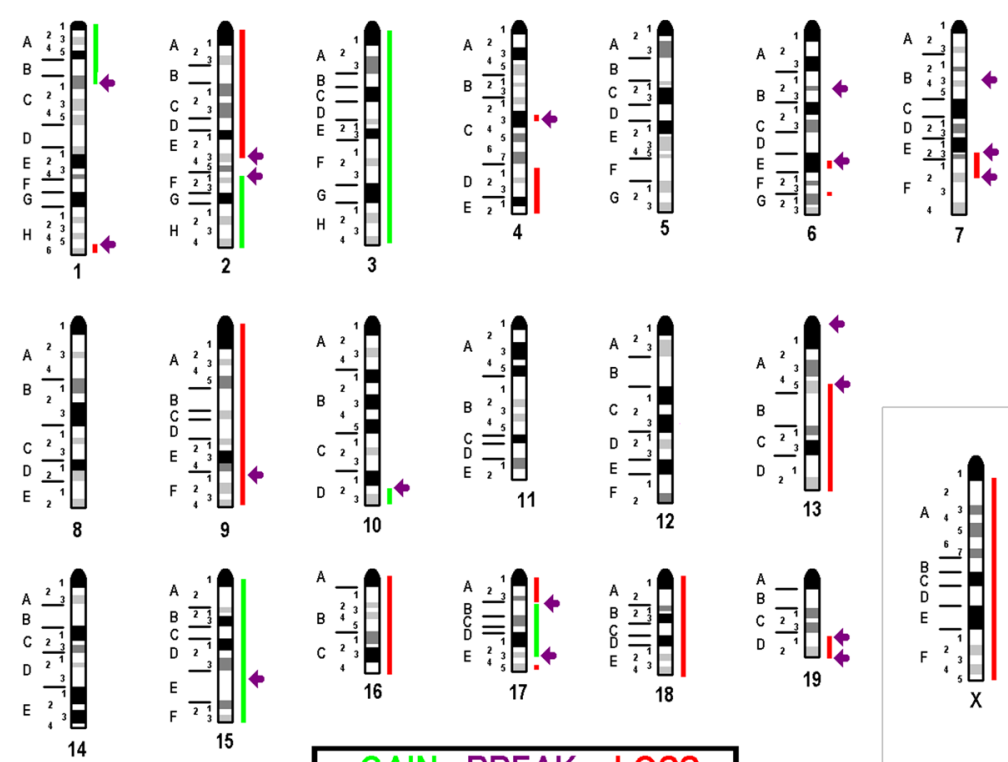

\section{GAIN BREAK LOSS}
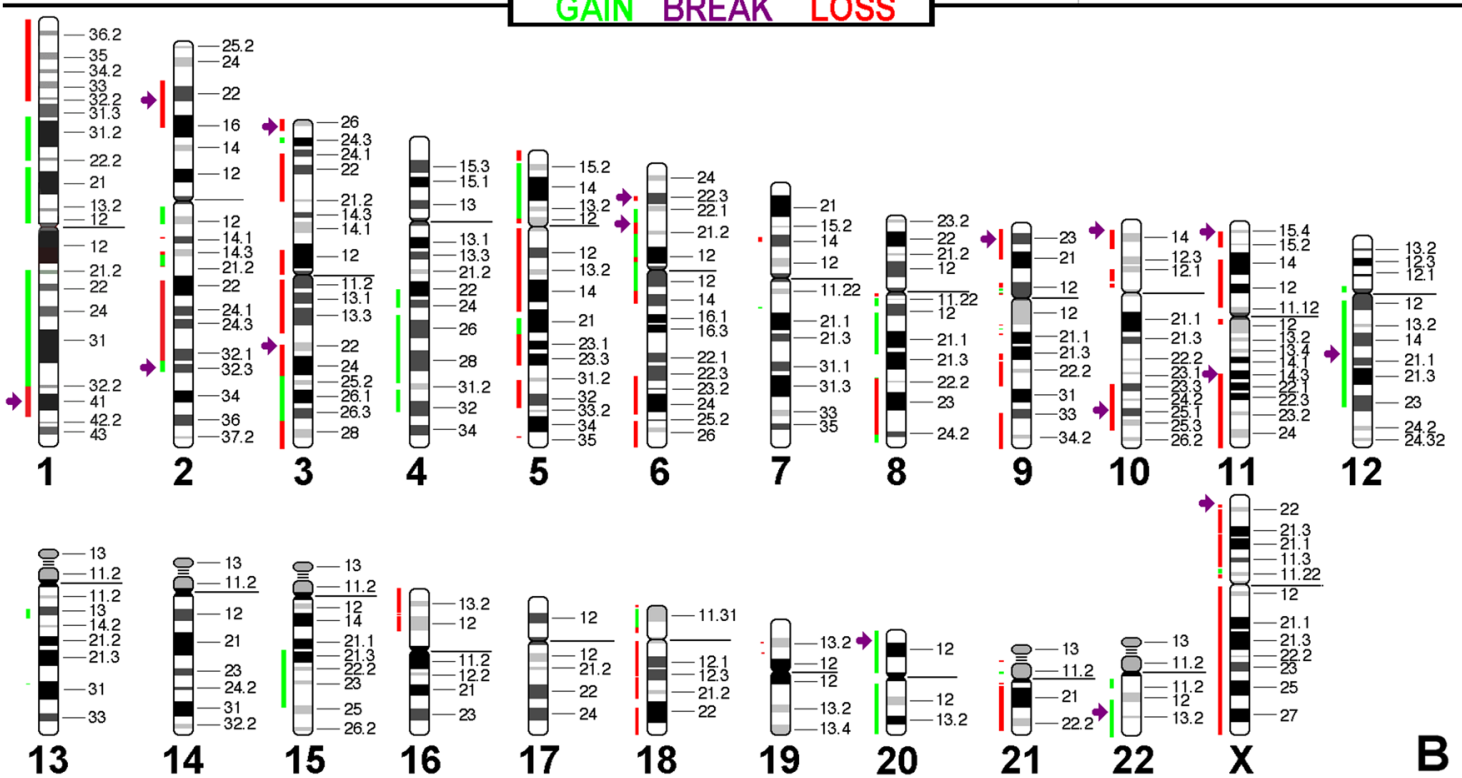

12

13 14 15 16 17 18 19 20 $2122 X$

Fig. 4 aCGH results for cell line AB1. In a copy number variations detected are summarized with respect to a tetraploid karyotype. Gains are depicted as green bars (one more copy= light green; two more copies=dark green), loss of one copy is depicted as a red bar and loss of two copies is depicted as a dark-red bar. Breaks are registered here as arrows. In $\mathbf{b}$ results of in silico translation for AB1 to human genome are shown the same way as in a

FISH results and also used to determine breakpoints of unbalanced rearrangements (Additional file 1: Table 1).

The cell lines A1 and AC29 were tetraploid; as in both cell lines derivative chromosomes were present twice, it is possible that polyploidization was a result of cell culture, and tetraploidy was absent in original tumor. Such so-called telomere-driven tetraploidization in the context of cell culture-related factors as trypsin treatment, increasing number of cell-culture passages, and oxygen exposure [29, 30] was discussed before. However, as no karyotype of tumor or early 

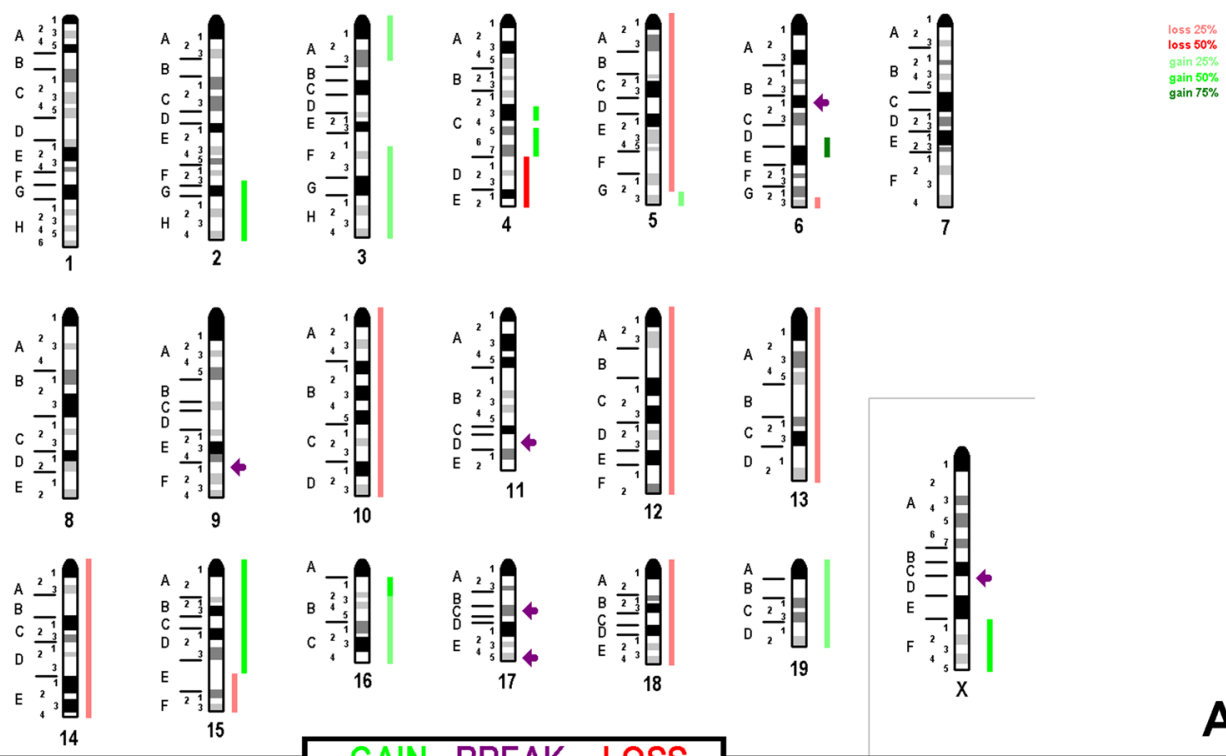

GAIN BREAK LOSS
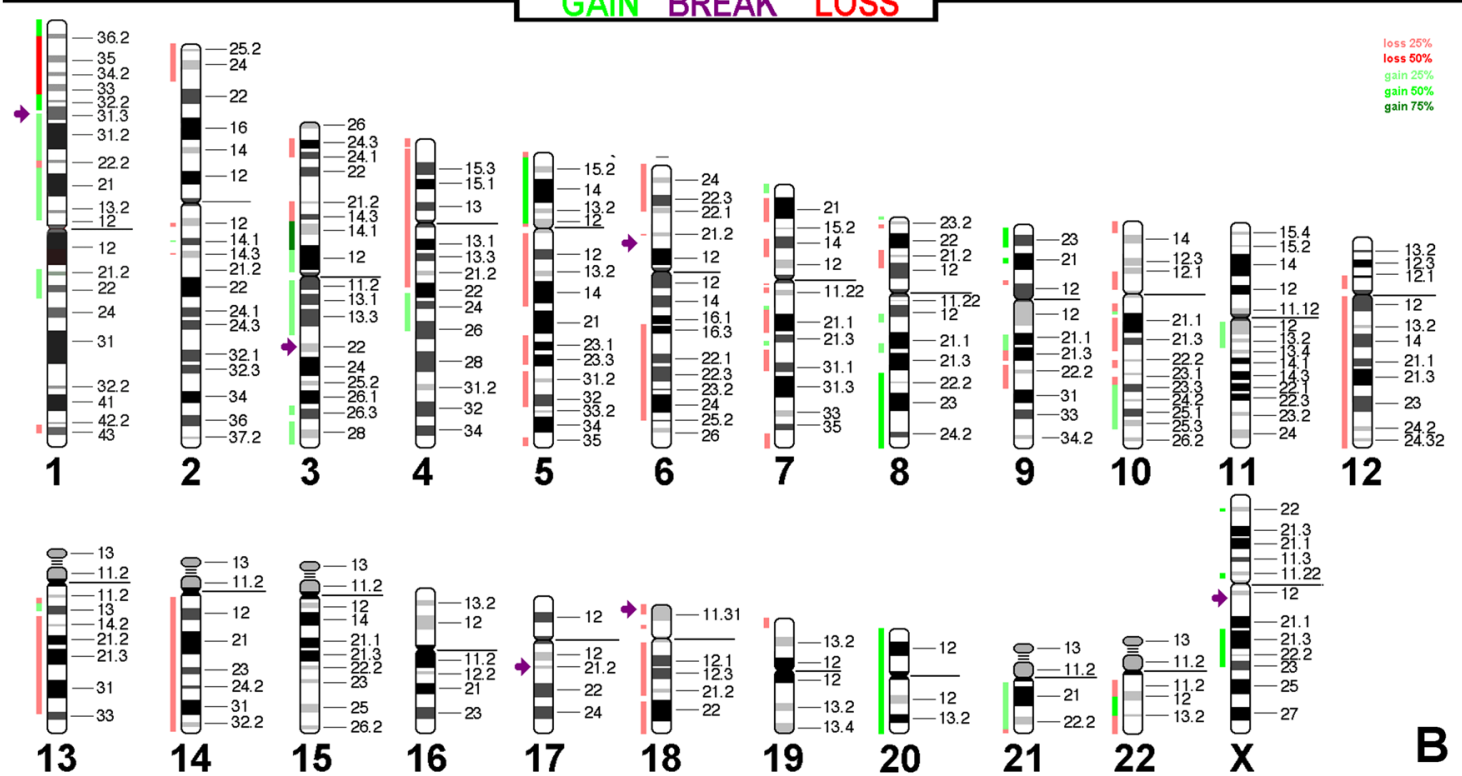

loss $50 \%$
gain $25 \%$
gain $50 \%$

Fig. 5 aCGH results for cell line AB22 depicted with respect to a tetraploid karyotype; legend like in Fig. 4

cell passages of A1 and AC29 are available, this is just speculation and cannot be tested by any means.

Interestingly, a deletion of $C D K N 2 A$ gene is considered as one of the most typical alterations in human MMs [7-9]. In the AB1 and AC29 there was indeed a deletion in the murine homologous region; however in cell line AB22 this region was duplicated (Additional file 1). For other tumor suppressor genes BAP1, NF2 and TP53 thought to play important roles in human
MMs [10-16], there is even less or no concordance in the copy number variant regions of the three cell lines (Additional file 1).

Nonetheless, the overall similarities of copy number variants found in the three murine MM cell lines compared to human MM are striking. A shown in Table 1 all three cell lines can serve as models for human epithelioid MM. As similarities are also high for sarcomatoid MM, also here they may be used as models 


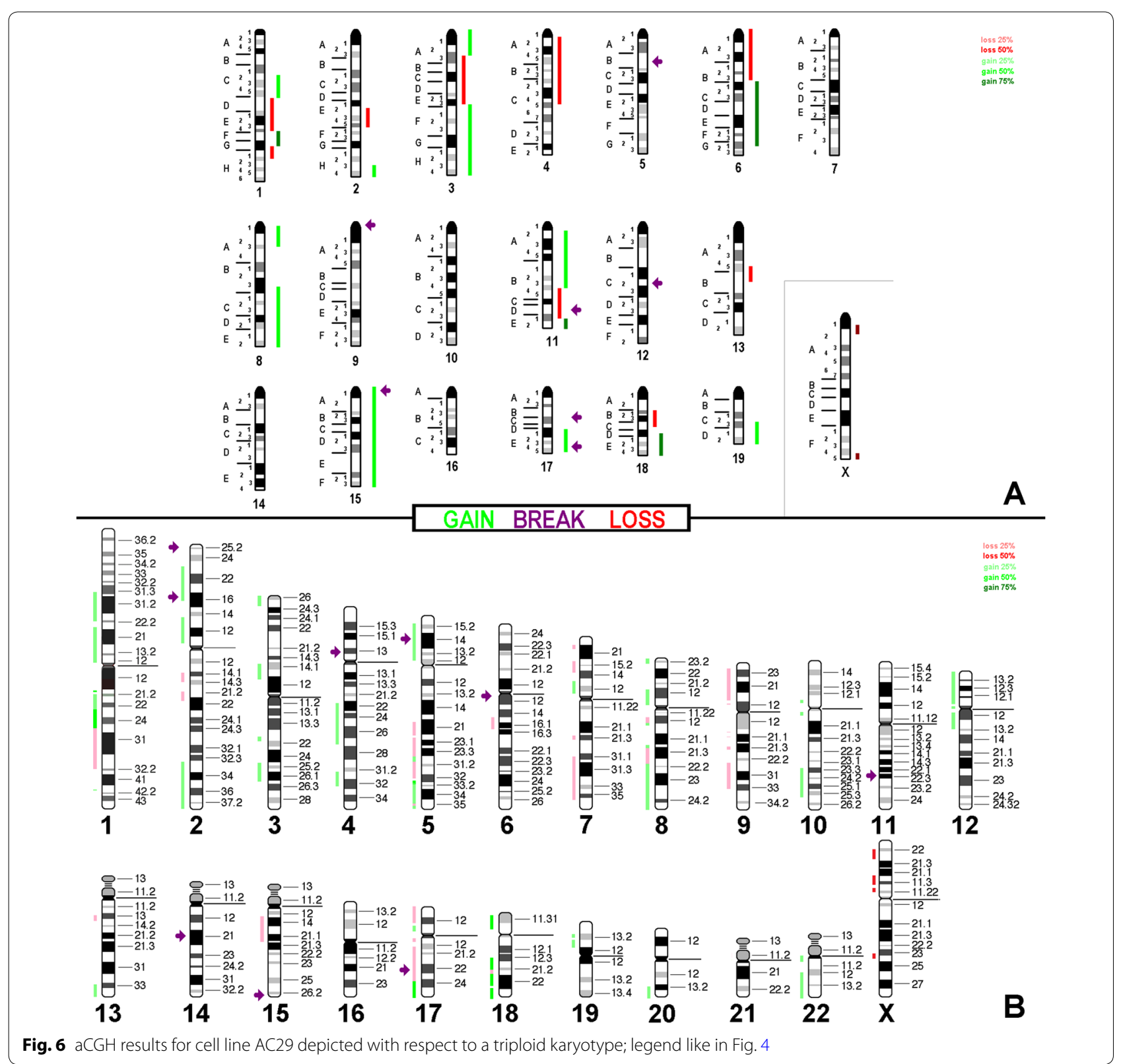

for. However, AB1, AB22 and AC29 are definitely not models for human biphasic MM.

\section{Methods}

Murine MM cell lines

The murine cell lines $\mathrm{AB} 1$ and $\mathrm{AC} 29$ were obtained from Cell Bank Australia (Westmead, Australia, order \#s CBA-0144 and CBA-0152) and AB22 European Collection of Authenticated Cell Cultures (Salisbury, UKorder\# ECACC 10092307). For this study, the cells were cultivated and divided into two portions, worked up cytogenetically (portion 1), and used to extract wholegenomic DNA (portion 2) as previously described [24].

\section{Molecular cytogenetics}

Fluorescence in situ hybridization (FISH) was performed as previously described [24]. "SkyPaintTM DNA Kit M-10 for Mouse Chromosomes" (Applied Spectral Imaging, Edingen-Neckarhausen, Germany) was used for multicolor-FISH (mFISH) applying whole chromosome 
Table 1 Comparison of 'translated' imbalances of murine MM-cellines AB1, AB22 and AC29 with human epitheloid, biphasic and sarcomatoid MM, according to Krismann et al. [22]

\begin{tabular}{|c|c|c|c|}
\hline CNV detected in cell lines $A B 1$ & Epithelial MM & Biphasic MM & Sarcomatoid MM \\
\hline del(1)(pter32) & $?$ & + & $(+)$ \\
\hline $\operatorname{amp}(1)(p 31 q 32)$ & + & - & $(+)$ \\
\hline $\operatorname{del}(2)(p 23 p 16)$ & + & - & - \\
\hline $\operatorname{amp}(2)(q 12 q 21.2)$ & $(+)$ & - & + \\
\hline del(2)(q22q32) & - & - & $?$ \\
\hline $\operatorname{del}(3)(p 22 p 10)$ & $?$ & - & + \\
\hline del(3)(q10q24) & $?$ & - & - \\
\hline $\operatorname{amp}(3)(q 25 q 26)$ & $?$ & $?$ & + \\
\hline del(3)(q27qter) & $?$ & $?$ & - \\
\hline amp(5)(p15p12) & + & - & + \\
\hline del(5)(p12q15) & $?$ & $?$ & + \\
\hline$a m p(6)(p 22.1 q 12)$ & $(+)$ & $(+)$ & $(+)$ \\
\hline del(6)(q22.3qter) & + & + & + \\
\hline $\operatorname{amp}(8)(q 11.2 q 21.2)$ & + & $(+)$ & + \\
\hline del(9)(pterqter) & + & + & + \\
\hline del(10)(p15p12) & + & + & + \\
\hline $\operatorname{del}(10)(q 23 q 25)$ & $(+)$ & $(+)$ & $(+)$ \\
\hline del(11)(pterp10) & $?$ & - & + \\
\hline del(11)(p10qter) & $?$ & + & + \\
\hline amp(15)(q21.2q24) & + & + & $?$ \\
\hline del(18)(p11.2qter) & + & $?$ & + \\
\hline amp(20)(pterqter) & + & - & $(+)$ \\
\hline del(21)(q11.1qter) & - & $?$ & $?$ \\
\hline del $(X)($ pterqter $)$ & + & - & - \\
\hline Sumfor + & $11 / 16$ & $6 / 19$ & $12 / 21$ \\
\hline Sum for $(+)$ & $3 / 16$ & $3 / 19$ & $5 / 21$ \\
\hline Sum for + and $(+)$ & $14 / 16$ & $9 / 19$ & $17 / 21$ \\
\hline CNV detected in cell lines AB22 & Epithelial MM & Biphasic MM & Sarcomatoid MM \\
\hline del(1)(pter32) & + & + & $(+)$ \\
\hline $\operatorname{amp}(1)(p 32 p 10)$ & + & - & + \\
\hline del(3)(p24p24) & + & - & $(+)$ \\
\hline del(3)(p21.2p14.2) & $?$ & $?$ & $(+)$ \\
\hline $\operatorname{amp}(3)(p 14.2 q 21)$ & + & + & + \\
\hline del(3)(q26qter) & $?$ & $?$ & - \\
\hline del(4)(pterq21.1) & + & + & + \\
\hline amp(5)(p15.3p12) & + & - & + \\
\hline del(5)(q11qter) & $?$ & $?$ & $(+)$ \\
\hline del(6)(q16q25) & + & + & + \\
\hline amp(7)(pterp22) & + & + & $?$ \\
\hline del(7)(p22qter) & - & - & + \\
\hline del(8)(p22p12) & + & + & + \\
\hline amp(8)(q22qter) & + & $(+)$ & + \\
\hline del(9)(q21.2q22.3) & $(+)$ & $(+)$ & $?$ \\
\hline del(10)(pterq23.2) & + & + & + \\
\hline $\operatorname{amp}(11)(q 11 q 13.3)$ & $?$ & - & $?$ \\
\hline del(12)(p12.1qter) & $?$ & - & + \\
\hline del(13)(q13q32) & + & + & + \\
\hline del(14)(q11qter) & + & + & + \\
\hline
\end{tabular}


Table 1 (continued)

\begin{tabular}{|c|c|c|c|}
\hline CNV detected in cell lines AB1 & Epithelial MM & Biphasic MM & Sarcomatoid MM \\
\hline del(18)(pterqter) & + & $(+)$ & + \\
\hline del(19)(pterp13.3) & $?$ & $(+)$ & $(+)$ \\
\hline amp(20)(pterqter) & + & - & $(+)$ \\
\hline $\operatorname{del}(22)(q 11.2 q 11.2)$ & + & + & + \\
\hline del(22)(q13.2qter) & + & + & + \\
\hline Sum for + & $17 / 20$ & $11 / 22$ & $15 / 23$ \\
\hline Sum for (+) & $1 / 20$ & $4 / 22$ & $6 / 23$ \\
\hline Sum for + and $(+)$ & $18 / 20$ & $15 / 22$ & $21 / 23$ \\
\hline CNV detected in cell lines AC29 & Epithelial MM & Biphasic MM & Sarcomatoid MM \\
\hline $\operatorname{amp}(1)(p 31 q 25)$ & - & - & $(+)$ \\
\hline $\operatorname{amp}(2)(p 23 p 11.2)$ & - & - & + \\
\hline amp(2)(q33qter) & + & - & + \\
\hline amp(3)(pterq24.3) & + & - & - \\
\hline amp(3)(p14.1p13) & + & + & $?$ \\
\hline $\operatorname{amp}(3)(q 25 q 26.2)$ & $(+)$ & $(+)$ & + \\
\hline amp(5)(p15.2p13.1) & + & - & + \\
\hline $\operatorname{del}(5)(q 21 q 32)$ & $?$ & $?$ & $(+)$ \\
\hline amp(5)(q33qter) & $?$ & + & - \\
\hline $\operatorname{del}(6)(q 15 q 16.1)$ & + & + & + \\
\hline del(7)(p21p15.1) & + & + & $?$ \\
\hline amp(7)(p13p11.1) & - & - & - \\
\hline del(7)(q21.3q36) & + & + & + \\
\hline amp(8)(p12p11.1) & + & - & - \\
\hline amp(8)(q22.2qter) & + & $(+)$ & + \\
\hline del(9)(pterq33) & + & + & + \\
\hline del(13)(q13q14.1) & + & + & + \\
\hline del(15)(q13q21.1) & - & - & $(+)$ \\
\hline del(17)(pterp12) & + & + & $(+)$ \\
\hline del(17)(q11q23) & $?$ & - & - \\
\hline amp(17)(q24qter) & + & - & $(+)$ \\
\hline amp(19)(p13.2p13.1) & $?$ & - & - \\
\hline amp(20)(q13.2qter) & + & - & + \\
\hline $\operatorname{del}(X)(p 22 p 11.2)$ & $(+)$ & - & - \\
\hline Sum for + & $14 / 20$ & $8 / 23$ & $10 / 22$ \\
\hline Sum for $(+)$ & $1 / 20$ & $2 / 23$ & $5 / 22$ \\
\hline Sum for + and $(+)$ & $15 / 20$ & $10 / 23$ & $15 / 22$ \\
\hline
\end{tabular}

Only imbalances present in any of the three human MMs are listed

$\mathrm{CNV}=$ copy number variation; $+=$ aberration present in the cell line, - absent in the cell line; $?=$ no clear correlation possible, as it can be + or - in human cases

paints, and murine chromosome-specific multicolor banding (mcb) probe mixes for FISH-banding [31]. At least 30 metaphases were acquired and analyzed for each probe set on a Zeiss Axioplan microscope, equipped with ISIS software (MetaSystems, Altlussheim, Germany). Array-based comparative genomic hybridization (aCGH) was completed according to standard procedures with "SurePrint G3 Mouse CGH Microarray, 4x180K" (Agilent Technologies, Santa Clara, CA, USA).
Data analysis and translation

The regions of imbalances and breakpoints in AB1, AB22 and AC29 were characterized after analyses of aCGH and mcb data, and aligned with their human homologous regions using Ensembl Genome Browser, as previously described [24]. The data we obtained was compared with the literature [22] (Tables 1 and 2). 
Table 2 The four tumor suppressor genes most often involved in human MM acc. to [7-16], being deleted and/ or mutated there are compared for copy number variant observed in the three studied cell lines

\begin{tabular}{llll}
\hline Human gene/murine homologue & AB1 & AB22 & AC29 \\
\hline BAP1 deletion 3p21.1 & $(+)$ & + & No CNV \\
CDKN2A deletion 9p21.2 & No CNV & No CNV & No CNV \\
TP53 deletion 17p13.1 & No CNV & No CNV & No CNV \\
NF2 deletion 22q12.2 & No CNV & No CNV & No CNV
\end{tabular}

Genomic locations (HG19/GRCh37): BAP1 - chr3:52,435,020-52,444,121; CDKN2A - chr9:21,967,751-21,994,490; TP53 - chr17:7,571,720-7,590,868; NF2 chr22:29,999,545-30,094,589

$+=$ partially deleted $(+)=$ possibly deleted; no $C N V=$ no copy number alteration; dup $=$ duplication instead of deletion

\section{Supplementary information}

Supplementary information accompanies this paper at https://doi. org/10.1186/s13039-020-00511-4.

Additional file 1:Table 1. The regions of gain and loss of copy numbers, as well of breakpoints of balanced rearrangements, observed in AB1, AB22 and $A C 29$ and the corresponding homologue regions in humans, are listed as cytoband and position (GRCh37/hg19).

\section{Abbreviations}

aCGH: Array comparative genomic hybridization; BAP1: Breast cancer associated gene 1 (BRCA1) associated protein 1 gene; CDKN2A: Cyclin-dependent kinase inhibitor $2 \mathrm{~A}$ gene; FISH: Fluorescence in situ hybridization; $\mathrm{mFISH}$ : Multicolor fluorescence in situ hybridization using all 21 murine whole chromosome paints as probes; MM: Malignant mesothelioma; mcb: Murine multicolor banding; NF2: Neurofibromatosis type 2 gene; TP53: Tumorsuppressorprotein 53 gene.

\section{Acknowledgements}

The technical support of Dr. Nadezda Kosyakova (Jena, Germany) is kindly acknowledged.

\section{Authors' contributions}

TL developed the idea for this study and got funded for it; EW and SA did the practical work and evaluated the FISH-results; MR did the practical work and evaluated the aCGH-results; TL and SA did final evaluation; AS drafted the paper; $T L$ wrote the final version which was approved by all coauthors. All authors read and approved the final manuscript.

\section{Funding}

Open access funding provided by Projekt DEAL. Supported by Grant \# 2013.032.1 of the Wilhelm Sander-Stiftung.

\section{Availability of data and materials}

All data generated or analysed during this study are included in this published article and its supplementary information files.

\section{Ethics approval and consent to participate}

According to the ethical committee (medical faculty) and the Animal Experimentation Commission of the Friedrich Schiller University there are no ethical agreements necessary for studies involving murine tumor cell lines.

\section{Competing interests}

The authors declare that they have no competing interests.

\section{Author details}

${ }^{1}$ Jena University Hospital, Institute of Human Genetics, Friedrich Schiller University, Am Klinikum 1, 07747 Jena, Germany. ${ }^{2}$ Croatian Institute for Brain
Research, School of Medicine, University of Zagreb, Salata 12, 10000 Zagreb, Croatia.

Received: 15 July 2020 Accepted: 19 August 2020

Published online: 09 September 2020

\section{References}

1. Attanoos RL, Pugh MR. The diagnosis of pleural tumors other than mesothelioma. Arch Pathol Lab Med. 2018;142:902-13.

2. Opitz I. Management of malignant pleural mesothelioma-the European experience. J Thorac Dis. 2014;6:S238-52.

3. Dragani TA, Colombo F, Pavlisko EN, Roggli VL. Malignant mesothelioma diagnosed at a younger age is associated with heavier asbestos exposure. Carcinogenesis. 2018;39:1151-6.

4. Hiddinga Bl, Rolfo C, van Meerbeeck JP. Mesothelioma treatment: Are we on target? A review. J Adv Res. 2015;6:319-30.

5. Solbes E, Harper RW. Biological responses to asbestos inhalation and pathogenesis of asbestos-related benign and malignant disease. J Investig Med. 2018;66:721-7.

6. Frost $\mathrm{G}$. The latency period of mesothelioma among a cohort of British asbestos workers (1978-2005). Br J Cancer. 2013;109:1965-73.

7. Matsumoto S, Nabeshima K, Kamei T, Hiroshima K, Kawahara K, Hata S, Marukawa K, Matsuno Y, Taguchi K, Tsujimura T. Morphology of 9p21 homozygous deletion-positive pleural mesothelioma cells analyzed using fluorescence in situ hybridization and virtual microscope system in effusion cytology. Cancer Cytopathol. 2013;121:415-22.

8. Sage AP, Martinez VD, Minatel BC, Pewarchuk ME, Marshall EA, MacAulay GM, Hubaux R, Pearson DD, Goodarzi AA, Dellaire G, Lam WL. Genomics and epigenetics of malignant mesothelioma. High Throughput. 2018;7:20.

9. Chapel DB, Schulte JJ, Husain AN, Krausz T. Application of immunohistochemistry in diagnosis and management of malignant mesothelioma. Transl Lung Cancer Res. 2020;9:S3-27.

10. Review Sekido Y. Molecular pathogenesis of malignant mesothelioma. Carcinogenesis. 2013;34:1413-9.

11. Yoshikawa Y, Sato A, Tsujimura T, Emi M, Morinaga T, Fukuoka K, Yamada S, Murakami A, Kondo N, Matsumoto S, Okumura Y, Tanaka F, Hasegawa S, Nakano T, Hashimoto-Tamaoki T. Frequent inactivation of the BAP1 gene in epithelioid-type malignant mesothelioma. Cancer Sci. 2012;103:868-74

12. Farzin M, Toon CW, Clarkson A, Sioson L, Watson N, Andrici J, Gill AJ. Loss of expression of BAP1 predicts longer survival in mesothelioma. Pathology. 2015:47:302-7.

13. Paajanen J, Laaksonen S, Kettunen E, Ilonen I, Vehmas T, Salo J, Räsänen J, Sutinen E, Ollila H, Mäyränpää MI, Myllärniemi M, Wolff H. Histopathological features of epithelioid malignant pleural mesotheliomas in patients with extended survival. Hum Pathol. 2020;98:110-9.

14. De Rienzo A, Testa JR. Malignant mesothelioma. Atlas Genet Cytogenet Oncol Haematol. 2018;22:403-6.

15. Hmeljak J, Sanchez-Vega F, Hoadley KA, Shih J, Stewart C, Heiman D, Tarpey P, Danilova L, Drill E, Gibb EA, Bowlby R, Kanchi R, Osmanbeyoglu HU, Sekido Y, Takeshita J, Newton Y, Graim K, Gupta M, Gay CM, Diao L, Gibbs DL, Thorsson V, lype L, Kantheti H, Severson DT, Ravegnini G, Desmeules $P$, Jungbluth AA, Travis WD, Dacic S, Chirieac LR, Galateau-Sallé F, Fujimoto J, Husain AN, Silveira HC, Rusch VW, Rintoul RC, Pass H, Kindler H, Zauderer MG, Kwiatkowski DJ, Bueno R, Tsao AS, Creaney J, Lichtenberg T, Leraas K, Bowen J, TCGA Research Network, Felau I, Zenklusen JC, Akbani R, Cherniack AD, Byers LA, Noble MS, Fletcher JA, Robertson AG, Shen R, Aburatani H, Robinson BW, Campbell P, Ladanyi M. Integrative molecular characterization of malignant pleural mesothelioma. Cancer Discov. 2018:8:1548-65.

16. de Assis LV, Isoldi MC. The function, mechanisms, and role of the genes PTEN and TP53 and the effects of asbestos in the development of malignant mesothelioma: a review focused on the genes' molecular mechanisms. Tumour Biol. 2014;35:889-901.

17. Patil NS, Righi L, Koeppen H, Zou W, Izzo S, Grosso F, Libener R, Loiacono M, Monica V, Buttigliero C, Novello S, Hegde PS, Papotti M, Kowanetz M, Scagliotti GV. Molecular and histopathological characterization of 
the tumor immune microenvironment in advanced stage of malignant pleural mesothelioma. J Thorac Oncol. 2018;13:124-33.

18. Micolucci L, Akhtar MM, Olivieri F, Rippo MR, Procopio AD. Diagnostic value of microRNAs in asbestos exposure and malignant mesothelioma: systematic review and qualitative meta-analysis. Oncotarget. 2016;7:58606-37.

19. Boffetta P, Donato F, Pira E, Luu HN, La Vecchia C. Risk of mesothelioma after cessation of asbestos exposure: a systematic review and metaregression. Int Arch Occup Environ Health. 2019;92:949-57.

20. Waterston RH, Lindblad-Toh K, Birney E, Rogers J, Abril JF, Agarwal P, Agarwala R, Ainscough R, Alexandersson M, An P, Antonarakis SE, Attwood J, Baertsch R, Bailey J, Barlow K, Beck S, Berry E, Birren B, Bloom T, Bork P, Botcherby M, Bray N, Brent MR, Brown DG, Brown SD, Bult C, Burton J, Butler J, Campbell RD, Carninci P, Cawley S, Chiaromonte F, Chinwalla AT, Church DM, Clamp M, Clee C, Collins FS, Cook LL, Copley RR, Coulson A, Couronne O, Cuff J, Curwen V, Cutts T, Daly M, David R, Davies J, Delehaunty KD, Deri J, Dermitzakis ET, Dewey C, Dickens NJ, Diekhans M, Dodge S, Dubchak I, Dunn DM, Eddy SR, Elnitski L, Emes RD, Eswara P, Eyras E, Felsenfeld A, Fewell GA, Flicek P, Foley K, Frankel WN, Fulton LA, Fulton RS, Furey TS, Gage D, Gibbs RA, Glusman G, Gnerre S, Goldman N, Goodstadt L, Grafham D, Graves TA, Green ED, Gregory S, Guigó R, Guyer M, Hardison RC, Haussler D, Hayashizaki Y, Hillier LW, Hinrichs A, Hlavina W, Holzer T, Hsu F, Hua A, Hubbard T, Hunt A, Jackson I, Jaffe DB, Johnson LS, Jones M, Jones TA, Joy A, Kamal M, Karlsson EK, Karolchik D, Kasprzyk A, Kawai J, Keibler E, Kells C, Kent WJ, Kirby A, Kolbe DL, Korf I, Kucherlapati RS, Kulbokas EJ, Kulp D, Landers T, Leger JP, Leonard S, Letunic I, Levine R, Li J, Li M, Lloyd C, Lucas S, Ma B, Maglott DR, Mardis ER, Matthews L, Mauceli E, Mayer JH, McCarthy M, McCombie WR, McLaren S, McLay K, McPherson JD, Meldrim J, Meredith B, Mesirov JP, Miller W, Miner TL, Mongin E, Montgomery KT, Morgan M, Mott R, Mullikin JC, Muzny DM, Nash WE, Nelson JO, Nhan MN, Nicol R, Ning Z, Nusbaum C, O'Connor MJ, Okazaki Y, Oliver K, Overton-Larty E, Pachter L, Parra G, Pepin KH, Peterson J, Pevzner P, Plumb R, Pohl CS, Poliakov A, Ponce TC, Ponting CP, Potter S, Quail M, Reymond A, Roe BA, Roskin KM, Rubin EM, Rust AG, Santos R, Sapojnikov V, Schultz B, Schultz J, Schwartz MS, Schwartz S, Scott C, Seaman S, Searle S, Sharpe T, Sheridan A, Shownkeen R, Sims S, Singer JB, Slater G, Smit A, Smith DR, Spencer B, Stabenau A, Stange-Thomann N, Sugnet C, Suyama M, Tesler G, Thompson J, Torrents D, Trevaskis E, Tromp J, Ucla C, Ureta-Vidal A, Vinson JP, Von Niederhausern AC, Wade CM, Wall M, Weber RJ, Weiss RB, Wendl MC, West AP, Wetterstrand K, Wheeler R, Whelan S, Wierzbowski J, Willey D, Williams S, Wilson RK, Winter E, Worley KC, Wyman D, Yang S, Yang SP, Zdobnov EM, Zody MC, Lander ES. Initial sequencing and comparative analysis of the mouse genome. Nature. 2002:420:520-62.
21. Davis MR, Manning LS, Whitaker D, Garlepp MJ, Robinson BWS. Establishment of a murine model of malignant mesothelioma. Int J Cancer. 1992:52:881-6.

22. Krismann M, Müller KM, Jaworska M, Johnen G. Molecular cytogenetic differences between histological subtypes of malignant mesotheliomas: DNA cytometry and comparative genomic hybridization of 90 cases. J Pathol. 2002;197:363-71.

23. Leibiger C, Kosyakova N, Mkrtchyan H, Glei M, Trifonov V, Liehr T. First molecular cytogenetic high resolution characterization of the $\mathrm{NIH}$ $3 T 3$ cell line by murine multicolor banding. J Histochem Cytochem. 2017:61:306-12.

24. Kubicova E, Trifonov V, Borovecki F, Liehr T, Rincic M, Kosyakova N, Hussein SS. First molecular cytogenetic characterization of murine malignant mesothelioma cell line AE17 and in silico translation to the human genome. Curr Bioinform. 2017;12:11-8.

25. Guja K, Liehr T, Rincic M, Kosyakova N, Hussein Azawi SS. Molecular cytogenetic characterization identified the murine B-Cell lymphoma cell line A-20 as a model for sporadic Burkitt's jymphoma. J Histochem Cytochem. 2017;65:669-77.

26. Rhode H, Liehr T, Kosyakova N, Rincic M, Azawi SSH. Molecular cytogenetic characterization of two murine colorectal cancer cell lines. OBM Genet. 2018;2:37.

27. Steinacker R, Liehr T, Kosyakova N, Rincic M, Hussein Azawi SS. Molecular cytogenetic characterization of two murine cancer cell lines derived from salivary gland. Biol Commun. 2018;63:243-55.

28. Azawi S, Liehr T, Rincic M, Manferrari M. Molecular cytogenomic characterization of the murine breast cancer cell lines C-127l, EMT6/P and TA3 Hauschka. Int J Mol Sci. 2020;21:E4716.

29. Davoli T, de Lange T. Telomere-driven tetraploidization occurs in human cells undergoing crisis and promotes transformation of mouse cells. Cancer Cell. 2012;21:765-76.

30. Mastromonaco GF, Perrault SD, Betts DH, King WA. Role of chromosome stability and telomere length in the production of viable cell lines for somatic cell nuclear transfer. BMC Dev Biol. 2006;6:41.

31. Liehr T, Starke H, Heller A, Kosyakova N, Mrasek K, Gross M, Karst C, Steinhaeuser U, Hunstig F, Fickelscher I, Kuechler A, Trifonov V, Romanenko SA, Weise A. Multicolor fluorescence in situ hybridization (FISH) applied to FISH-banding. Cytogenet Genome Res. 2006;114:240-4.

\section{Publisher's Note}

Springer Nature remains neutral with regard to jurisdictional claims in published maps and institutional affiliations.
Ready to submit your research? Choose BMC and benefit from:

- fast, convenient online submission

- thorough peer review by experienced researchers in your field

- rapid publication on acceptance

- support for research data, including large and complex data types

- gold Open Access which fosters wider collaboration and increased citations

- maximum visibility for your research: over 100M website views per year

At BMC, research is always in progress.

Learn more biomedcentral.com/submissions 